\title{
Is pain perception altered in people with depression? A systematic review and meta-analysis of experimental pain research
}

\author{
Trevor Thompson a , PhD, Christoph U. Correll ${ }^{b}$, MD, Katy Gallop ${ }^{c}$, MSc, Davy \\ Vancampfort $^{\mathrm{d}, \mathrm{e}}, \mathrm{PhD}$, Brendon Stubbs ${ }^{\mathrm{f}, \mathrm{g}}, \mathrm{PhD}$
}

\begin{abstract}
${ }^{\mathrm{a}}$ Faculty of Education and Health, University of Greenwich, London SE9 2UG, UK
${ }^{\text {b} Z u c k e r ~ H i l l s i d e ~ H o s p i t a l, ~ L o n g ~ I s l a n d ~ J e w i s h ~ M e d i c a l ~ C e n t e r, ~ G l e n ~ O a k s, ~ N Y ~ 11004, ~ U S A ~}$

${ }^{\mathrm{c}}$ Acaster Consulting, London SE3 7HU, UK

${ }^{\mathrm{d}}$ KU leuven, UPC Z.org, Leuvensesteenweg 517, B-3070 Kortenberg, Belgium

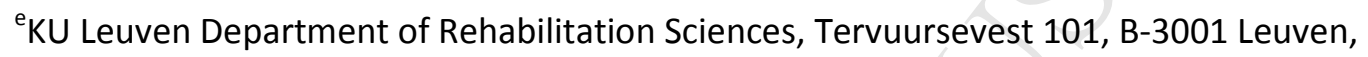
Belgium

${ }^{f}$ Physiotherapy Department, South London and Maudsley NHS Foundation Trust, London SE5 $8 \mathrm{AZ}$, UK

${ }^{8}$ Health Service and Population Research Department, Institute of Psychiatry, Psychology and Neuroscience, King's College London, De Crespigny Park, London SE5 8AF, UK
\end{abstract}

\section{Corresponding Author:}

Trevor Thompson

Email: t.thompson@gre.ac.uk

Telephone: +442083319632

\section{Disclosures}

BS, TT and KG have no conflicts of interest.

Dr. Correll has been a consultant and/or advisor to or has received honoraria from AbbVie, Actavis, Alkermes, Bristol-Myers Squibb, Eli Lilly, Genentech, Gerson Lehrman Group, IntraCellular Therapies, Janssen/J\&J, Lundbeck, MedAvante, Medscape, Otsuka, Pfizer, ProPhase, Reviva, Roche, Sunovion, Supernus, and Takeda. He has received grant support from Bristol-Myers Squibb, Otsuka, and Takeda.

Dr Davy Vancampfort is funded by the Research Foundation - Flanders (FWO-Vlaanderen). 


\section{Abstract}

While clinical studies suggest depressed patients may be more vulnerable to pain, experimental research is equivocal. This meta-analysis aimed to clarify whether depression is associated with altered pain perception in response to noxious stimulation and to identify factors that might influence this association. A search of major electronic databases was conducted to identify experimental studies investigating pain response in depressed participants vs. healthy controls using established pain outcome measures. Random effects meta-analysis of standardized mean differences was conducted on data from 32 studies $(\mathrm{N}=1,317)$. For high-intensity noxious stimulation, overall pain tolerance was similar across depressed and control groups (Hedge's $g=0.09, p=0.71$, studies=10). For low-intensity stimulation, a small, but statistically significant higher mean sensory threshold ( $g=0.35$, $p=0.01$, studies $=9)$ and pain threshold ( $g=0.32, p=0.02$, studies $=25)$ was observed in depressed participants, suggesting diminished pain. However, considerable heterogeneity in the direction and magnitude of effects was observed, indicating a likely condition-specific impact of depression on pain. Subgroup analysis found that pain threshold/tolerance was increased in depression for exteroceptive (cutaneous) stimulation but decreased for interoceptive (ischemic) stimulation, but that substantial heterogeneity remained. Overall, results provide some support for altered pain processing in depression, but suggest this link is dependent upon modality and additional, unidentified factors.

\section{Perspective}

This meta-analysis of experimental studies suggests potential effects of depression on pain perception are variable and likely to depend upon multiple factors. The contrasting pattern for ischemic vs. other noxious stimuli suggests that stimulus modality is a key factor, which could help explain discrepancies across clinical and experimental findings.

Key words: Depression; depressive disorder; pain; meta-analysis; systematic review. 


\section{Introduction}

Depression and pain are frequently observed as comorbid conditions in clinical settings. They represent two of the leading predictors of years lived with disability across the world ${ }^{73}$, and appear to interact to prove costlier and more disabling than the sum of their individual effects $^{2}$. Patients with depression often present with medically unexplained somatic complaints, such as abdominal pain, back pain and headache ${ }^{35}$, with mean pain prevalence estimated as $65 \%^{2}$ compared to around $29 \%$ for non-depressed populations ${ }^{15}$. Moreover, the presence of depression may predict future musculoskeletal pain ${ }^{40}$ and is a key risk factor for chronic low back pain ${ }^{53}$ suggesting a causal influence. The biochemical theory of depression suggests that a neurochemical imbalance of monoamines (e.g. serotonin) underlies depression and, given that these neurotransmitters are likely to play a key role in modulatory pain pathways, this may lead to altered pain perception ${ }^{2,27}$. Neural mechanisms common to depression and pain have also been implicated, with areas of the brain linked to mood (e.g. amygdala, insular) also sending numerous projections to key structures involved in pain modulation (e.g. periaqueductal gray) $)^{2,22}$.

If pain perception abnormalities are a manifestation of depression, this may have important treatment and diagnostic implications. For example, Fishbain et al. ${ }^{24}$ found that the impact of antidepressant medication on depression response/remission may be impaired when pain is present. Pain may also influence diagnostic accuracy, with failure to accurately diagnose major depression by physicians estimated to exceed $50 \%^{31,46}$, with presence of painful symptoms being central to misdiagnosis ${ }^{13,32}$. One large review found that $69 \%$ of individuals experiencing depression tended to disclose only somatic symptoms ${ }^{59}$, explaining why depression is frequently misdiagnosed as a somatic illness ${ }^{71}$. The consequences of failing to recognize depression can be severe, as untreated depression often becomes worse, leading to poorer outcomes ${ }^{55}$. 
Pain perception abnormalities in depression have also been examined using experimental paradigms to provide a level of control difficult to achieve in clinical settings, and to facilitate the assessment of pain across multiple dimensions, including subjective, behavioral and psychophysiological responses. Surprisingly, a preliminary meta-analysis of six experimental studies ${ }^{16}$ found decreased pain in depressed groups relative to healthy controls. Whilst informative, a considerable number of studies have been conducted since the publication of the original review 13 years ago. Furthermore, limited data availability restricted the review to an examination of pain threshold only, which assesses minimal intensity pain ${ }^{75}$, and which in isolation is of limited clinical relevance. Since this review, there has been mounting interest in depression and pain perception with many experimental studies conducted over the past decade, producing equivocal findings. One possible explanation for this equivocality is that the link between depression and pain perception may be dependent upon the type of noxious stimulus used, with one theory ${ }^{37}$ suggesting that different sources of pain (e.g. exteroceptive vs. interoceptive) are subserved by distinct pain inhibitory systems and these can be affected differentially by depression. While preliminary evidence appears to supports this theory, the influence of stimulus modality as a possible moderator has yet to be subject to systematic review. To better understand the link between depression and pain, there is a pressing need to provide an updated review and synthesis of the recent experimental pain literature, examining potential moderators and more clinically relevant measures, such as pain tolerance ${ }^{75}$, pain affect and pain intensity ratings.

Therefore, we conducted a comprehensive systematic review and meta-analysis comparing depressed and healthy control groups in their response to experimentally-induced pain. Specific aims were to examine: (1) whether depressed vs. healthy controls differed in sensitivity to experimentally-administered noxious stimuli, (2) whether differences would 
be confined to specific pain outcomes, and (3) which variables moderated the observed effects.

\section{Method}

This systematic review was conducted in accordance with the MOOSE guidelines ${ }^{64}$ and the PRISMA statement ${ }^{47}$.

\section{Eligibility criteria}

Studies were included that utilized: (1) a group with current depression, as defined by a primary diagnosis of a depressive disorder based on a clinical instrument (e.g. DSM, ICD) or a standardized questionnaire (e.g. the Beck Depression Inventory); (2) a comparative control group of healthy, non-depressed individuals; (3) an experimental sensory stimulus; and (4) at least one of the following outcome measures: pain threshold, pain tolerance, pain ratings or sensory threshold.

Studies were excluded if: (1) depression was a secondary diagnosis, (2) depressed groups suffered from a chronic pain condition, (3) classification as depressed was based on experimental mood induction, or (4) pain perception was assessed during an experimental manipulation of mood or attention.

\section{Information sources and search details}

Two independent reviewers (KG, TT) searched EMBASE, MEDLINE, PsycINFO and the Web of Science from database inception until $7^{\text {th }}$ April, 2015. Our search used a widely inclusive strategy, identifying articles that contained appropriate combinations of broad and specific keywords relating to eligibility criteria; precise search term combinations are reported in Table S1 along with number of hits returned for the Medline database as an exemplar. Due 
to the large number of results, studies reporting randomized clinical trials were excluded and the search results were refined using limits of human studies and English language. Additional studies were identified from reference lists of relevant articles.

\section{Study selection}

After removal of duplicates, two reviewers (KG, TT) screened titles and abstracts for eligibility, and developed a list of full text articles through consensus. Two authors (TT, BS) considered the full texts of included articles and a final list of eligible articles was agreed. We contacted authors up to 3 times over a month to clarify study eligibility and/or acquire additional data.

\section{Outcomes}

Multiple primary outcomes were used to capture different aspects of pain response ${ }^{25}:$ (1) pain threshold (the point at which pain is first perceived), (2) pain tolerance (the point at which pain can no longer be tolerated), and (3) self-reported ratings of pain intensity/affect. Sensory threshold (the point at which sensation is first perceived) was included as a secondary outcome to investigate whether differences in pain perception were accompanied by differences in non-painful sensory perception.

\section{Data Extraction}

Study data were extracted independently by two authors (TT, KG) using a standardized extraction form that we have used in several of our previous studies ${ }^{65,66}$ but with a few, relatively minor adaptations for the topic of depression and pain perception, so coding protocols were very clear and unambiguous. Details were recorded for pain induction method, pain assessment outcome, depressed group (demographics, diagnostic method, symptom severity, antidepressant medication), control group (demographics), study design 
and geographical location. We recorded group means and standard deviations for each pain outcome measure, or any other available information that would allow computation of effect size (see 'Meta-Analysis' section below). To minimize reporting bias, authors were also contacted for statistical details when non-significant findings were reported but in insufficient detail to allow computation of effect sizes.

When a study reported pain outcome data at different time points, we extracted averaged data if available, otherwise we extracted data at the first time point. When outcome data were collected at multiple stimulus intensities (usually applicable to electrical stimulation), the highest intensity was extracted as this was most likely to reliably evoke pain. When a study applied noxious stimulation to both left and right sides of the body, we used pain scores averaged across sites where possible, otherwise we extracted data from the right side as this was the most common site tested and may show greater sensitivity to detecting differences in pain response and increased homogeneity in our analyses ${ }^{4}$. From studies reporting pain data in participants before and after antidepressant treatment, we used unmedicated data for the overall pooled analyses, but we used data from treated patients for the medicated/unmedicated subgroup analysis. Finally, a few studies used sensory decision theory to yield two measures of pain threshold: response criterion and d-prime (sensory discrimination). Response criterion was abstracted as the data of interest, as this measure is the most closely related to verbally declared pain threshold used in the other included studies ${ }^{25}$.

\section{Methodological study appraisal}

Two authors (TT, BS) independently completed methodological quality assessment of

included articles using the case-control Newcastle Ottawa Scale ${ }^{74}$ (NOS). If any 
disagreement arose, a third author (CC) was available for mediation. The NOS provides an assessment of the methodological quality of non-randomized trials and its content validity and reliability have been established. Included studies are judged on 9 items across three key areas: selection of the participants, comparability of the participants, and outcomes. Each study receives an overall score for methodological quality of up to 9 points (one for each item) and scores of 5 and above are considered to reflect satisfactory study quality ${ }^{74}$.

\section{Meta-analysis}

As we anticipated heterogeneity in effect sizes due to variation in important study characteristics typical in experimental pain research, a random effects model using the method of moments was chosen. This allows heterogeneity to be accounted for statistically and permits generalization to studies beyond those examined in the meta-analysis. Hedges's $g$ was calculated as the effect size based on standardized differences in pain scores between participants with depression and controls. All analysis was performed using Comprehensive Meta-Analysis software (CMA, version 3). When computing Hedge's $g$, if a study used multiple pain inductions we used the averaged pain score, or if this was not available, we used scores for heat/cold or electrical modalities, as these were the most commonly reported (as the choice of these modalities might have some influence on the overall effect size, we also computed effect sizes for each stimulus modality separately in subgroup analysis). If a study reported data from participants before and after anti-depressant medication we included only unmedicated data for overall analyses. Analysis of pain ratings was performed only for studies where stimulation intensity was equivalent for both groups (i.e. equal time/temperature), to avoid confounding of differences in pain ratings with differences in stimulus intensity. Analysis was conducted as described below. 
First, we compared pain scores in depressed vs. control groups for each primary outcome of (1) pain threshold, (2) pain tolerance and (3) pain ratings and for the secondary outcome of sensory threshold. Heterogeneity was examined with Cochran's $Q$ and $I^{2}$ statistics to assess inconsistency of effect sizes across all studies for each pain outcome ${ }^{28}$. Cochran's $Q$ tests the assumption that all studies share a common effect size, with $p<.05$ used here to indicate a difference in true effect size across compared studies. $I^{2}$ provides an estimate of the proportion of the total variation in effect sizes across studies that can be attributed to genuine heterogeneity in effect size. Higgins et al. ${ }^{28}$ suggest guidelines of $25 \%, 50 \%$ and $75 \%$ can be used as rough approximations for low, medium and high heterogeneity. Publication bias was assessed with a visual inspection of funnel plots and with the Begg-Mazumdar Kendall's tau ${ }^{8}$ and Egger's bias test ${ }^{20}$. If we encountered publication bias, we calculated the trim and fill adjusted analysis ${ }^{17}$ to remove the most extreme small studies from the positive side of the funnel plot, and recalculated the effect size at each iteration, until the funnel plot was symmetric around the new effect size.

Second, we conducted subgroup analysis for pain threshold and tolerance (limited data prohibited subgroup analysis of other outcomes). As a primary interest was to determine whether depressed vs. control group differences were influenced by stimulus modality, we conducted separate analyses for each modality. We used Cochran's $Q$ to test for overall differences in effect size across modalities, and if significant, used follow-up Z-tests to compare each individual modality vs. every other modality ${ }^{11}$. We also performed separate analysis for medicated/unmedicated subgroups, and examined whether results were similar when restricting the sample to patients with major depressive disorder (MDD) only.

Third, we performed meta-regression analysis to examine whether group differences were influenced by mean study age, gender composition and magnitude of depressive symptoms in the depressed group. Generally, meta-regression was performed only when at least 10 
studies were available for analysis ${ }^{29}$, although mean age for pain tolerance was also included as the 9 studies available closely approximated this guideline. Pseudo- $R^{2}$, an index of the amount of estimated true heterogeneity in effect size that can be accounted for by the covariates was also computed. Separate meta-regression analyses were performed for each moderator variable.

Finally, for studies that assessed pain perception before and after antidepressant treatment, we pooled within-subject changes in each pain outcome measure using pre and post means and SDs for both groups in order to assess the effect of antidepressant treatment on pain measurements.

\section{RESULTS}

\section{Study characteristics}

Initial searches yielded 5095 unique hits including 4 records identified through manual searching of reference lists. After screening, 65 articles were retained for full text review of which 33 were excluded (see Figure 1). Altogether, 32 studies were retained for analysis (Table 1).

Figure 1 here

Table 1 here

Across the 32 retained studies there were 30 unique studies with an aggregated total of 1317 participants (depression $n=641$, control $n=676$ ). The two non-unique studies ${ }^{48,62}$ were linked to two companion papers ${ }^{56,63}$ that used the same sample but provided different 
outcome data. Twenty-five studies matched depressed and control samples for age/gender or reported no differences, 2 studies reported age/gender differences and 3 studies did not report comparisons. The mean age of the depressed samples was 39.3 years (24.5-59.7 years) and the mean gender composition was $74.0 \%$ female (26-100\%). The mean illness duration, reported in 6 studies, was 8.7 years (2-19 years). For controls, the mean sample age was 38.0 years (23.9-53.7 years), with a mean gender composition of $71.4 \%$ female. Overall, 8 studies were conducted in North-America, 19 in Europe and 2 in South-America, with 1 study not specifying region. Studies most commonly used MDD only ( $k=21$ studies), as the depressed group, followed by other diagnosed depressive disorders, e.g. persistent depressive disorder $(k=5)$, and depressive syndrome based on depression severity assessed with a screening questionnaire, e.g. the Beck Depression Inventory $(B D I)^{7}(k=4)$. Depressive symptoms were measured in 24 studies, with the most commonly used measure the Hamilton Depression Rating Scale $(H A M D)^{26} \quad(k=13)$, followed by the BDI $(k=10)$. Antidepressant treatment status was reported as either unmedicated ( $k=16)$, fully medicated $(k=6)$ or mixed medicated/unmedicated $(k=7)$, with two studies providing data on the same sample before and after antidepressant treatment ${ }^{4,5}$. Three studies did not report medication status. A study average of $31.4 \%$ (range $0-100$ ) of depressed patients were treated with antidepressants at baseline (19 studies provided this information). The following pain induction methods were used: heat $(k=17)$, cold $(k=7)$, electrical $(k=8)$, ischemia by tourniquet procedure $(k=6)$, pressure $(k=4)$, laser $(k=1)$.

Mean total NOS score across studies was 5.1 with a range of 4-6 (Table 1). Individual quality criteria least frequently addressed included participant selection and experimenter blinding. More specifically, several studies employed hospital controls and many studies provided inadequate descriptions of recruitment procedures for depressed participants and/or controls, introducing the potential for selection bias or non-representativeness. In addition, 
most studies did not report use of experimenter blinding, inviting the possibility of bias in the assessment of pain, although the influence of this might be expected to be minimal given the type of pain assessments used. Intra-class correlations and Cohen's Kappa indicated adequate inter-rater agreement for total NOS scores, $\operatorname{ICC}(A, 2)=0.51$, and excellent $^{36}$ agreement on coding decisions for categorical (Kappa $=0.87-1.00$ ) and continuous (ICCs= 0.89-1.00) data, except for extracted SDs (ICC=0.05-0.07). The latter was due to two articles misreporting SEMs as SDs and was resolved by further statistical investigation, with $100 \%$ agreement on all decisions reached after consultation with the third rater (CC).

\section{Meta-analysis results}

Details of all meta-analysis results are presented in Table 2, with key findings for each outcome measure summarized below.

\section{Pain threshold}

In the pooled analysis, 25 studies including 567 people with depression and 587 controls demonstrated a higher overall pain threshold (i.e., reduced pain) in people with depression compared to controls, $g=0.32,95 \% \mathrm{Cl}[0.05,0.59], p=0.02$. There was no evidence of publication bias (Egger $=1.0, p=0.68 ;$ Begg $=0.15, p=0.69$ ). However, statistically significant $(Q=117, p<.01)$ and high $\left(I^{2}=77 \%\right)$ heterogeneity was observed, with effect sizes varying across studies in both magnitude and direction (Figure 2). Given this variation, subgroup analyses were conducted to identify possible moderating variables.

Figure 2 here 


\section{Subgroup analysis of pain threshold}

Individuals with depression exhibited reduced pain threshold (i.e., increased pain) in all 5 studies that employed ischemic pain induction ( $g=-0.81,95 \% \mathrm{Cl}[-1.39,-0.24], \mathrm{p}=.006)$, reversing the pattern of results seen for other pain induction methods (Table 2). Cochran's $Q$ revealed a significant overall difference in effect size across modalities $(Q=10.2, p=.017)$, with Z-tests showing effect size to be significantly different for ischemic compared to other modalities ( $\left.z^{\prime} s=5.25-6.98, p<.0001\right)$, with no other significant differences between other modalities.

When MDD-only studies ( $k=17)$ were examined, significantly greater pain threshold was observed for depressed participants relative to controls ( $g=0.38,95 \% \mathrm{Cl}[0.02,0.75], p=0.03$ ). The same was true for unmedicated $(\mathrm{g}=0.32,95 \% \mathrm{Cl}[0.01,0.70], \mathrm{p}=0.04, \mathrm{k}=15)$, but not in medicated individuals $(\mathrm{g}=0.16,95 \% \mathrm{Cl}[-0.55,0.89], \mathrm{p}=0.63, \mathrm{k}=5)$.

Although subgroup analyses indicate that effect sizes may be influenced by stimulus modality, estimates of $\mathrm{I}^{2}$ (Table 2 ) did not noticeably diminish (with the possible exception of the cold stimulus), suggesting that considerable heterogeneity remains even when stimulus modality is accounted for.

\section{Meta-regression of pain threshold}

In meta-regression analysis, depressive symptom severity (analyzing only studies that used the HAM-D, which was most commonly employed rating scale, in order to increase homogeneity of the findings), sex, age or study quality (NOS scores) were not significantly related to group differences in pain threshold ( $k=12-25$ studies, $\beta=.00-.24, p=0.14-0.99)$; see Table S2 for full results. Meta-regression was not performed on duration of illness as only 6 pain threshold studies provided this data. 


\section{Pain tolerance}

Pooling data across 10 studies from 199 people with depression and 215 controls, no overall difference in pain tolerance was observed, $\mathrm{g}=0.09,95 \% \mathrm{Cl}[-0.39,0.57], \mathrm{p}=0.71$ (figure S1). There was no evidence of publication bias (Begg=-0.26, $p=0.28$, Egger=-4.1, $p=0.16$ ). Similar to pain threshold, a high level of heterogeneity was observed $\left(I^{2}=71 \%\right)$, so subgroup analyses were conducted.

\section{Subgroup analysis of pain tolerance}

Depressed participants exhibited significantly reduced pain tolerance (i.e., increased pain) in response to ischemic pain induction ( $g=-0.76,95 \% \mathrm{Cl}[-1.04,-0.47], \mathrm{p}<0.001, \mathrm{k}=6)$, but without significant differences observed for other pain modalities (Table 2). Cochran's $Q$ showed a significant difference in effect sizes across modalities overall $(Q=12.64, p<.01)$. Ztests found effect sizes to be significantly different for ischemic vs. other modalities ( $\left.z^{\prime} s=4.39-6.24, p<.0001\right)$, with no other paired comparison being statistically significant. As with pain threshold, although significant differences in effect sizes across modalities were observed, heterogeneity was not notably diminished when subgroups were examined separately, with the exception of ischemic pain $\left(1^{2}=0\right)$.

The lack of overall group differences in pain tolerance in the pooled sample was confirmed in the subgroup of unmedicated participants, $g=0.02,95 \% \mathrm{Cl}[-0.54,0.56], p=0.97], k=7$, (only two studies of tolerance with medicated participants were available, so these were not examined). When studies with major depressive disorder only samples were analyzed, depressed participants showed higher tolerance than controls, but this finding did not reach significance ( $g=0.41,95 \% \mathrm{Cl}[-0.18,0.99], p=0.18, k=4)$. 


\section{ACCEPTED MANUSCRIPT}

Meta-regression of moderators of pain tolerance

Although no overall group differences in pain tolerance were found in the previously reported meta-analysis, meta-regression was conducted to examine whether group differences might be influenced by age, gender or study quality. However, differences between depressed and control groups were not significantly moderated by any of these variables (Table S2).

\section{Pain ratings}

Pooling data from 155 people with depression and 193 controls across 8 studies yielded no significant between-group differences in ratings of pain intensity $(\mathrm{g}=0.00,95 \% \mathrm{Cl}[-0.37$, 0.37], $p=0.97)$. Similarly, pooling data from 4 studies, including 99 people with depression and 118 controls, demonstrated no significant group differences in pain affect $(g=-0.37,95 \%$ $\mathrm{Cl}[-1.29,0.55], \mathrm{p}=0.43)$.

\section{Sensory threshold}

Pooling data from 9 studies, including 178 people with depression and 178 controls, sensory threshold was significantly higher in people with depression, $\mathrm{g}=0.35,95 \% \mathrm{Cl}[0.08,0.62]$, $p=0.01$ (Figure S2). There was some evidence of publication bias (Egger=4.7, $p=0.05)$, but the effect size remained unchanged when we calculated Duval and Tweedie trim and fill method $(0.35,95 \% \mathrm{Cl}[0.08,0.62])$.

Table 2 


\section{Changes in pain response before and after medication}

Two studies ${ }^{4,5}$ investigated differences in pain threshold, tolerance and sensory threshold using heat induction among a total of 42 people with MDD before and after antidepressant medication and 42 matched controls at equivalent before/after time points. Following antidepressant medication, the difference in pain threshold between depressed and control participants was significantly reduced $(\mathrm{g}=-0.57,95 \% \mathrm{Cl}[-1.01,-0.12], \mathrm{p}=0.01)$ as was sensory threshold ( $g=-0.44,95 \% \mathrm{Cl}[-0.88,-0.01], p=0.04)$. No significant effects were observed for pain tolerance $(\mathrm{g}=0.25,95 \% \mathrm{Cl}[-0.18,0.69], \mathrm{p}=0.20)$ after antidepressant medication.

\section{Discussion}

The current review is the largest and most comprehensive meta-analysis investigating responses to experimentally-induced pain in people with depression vs. healthy controls. Several key findings emerged from the study: (1) Pooled mean pain threshold ( $g=0.32$ ) and sensory threshold $(\mathrm{g}=0.35$ ) were higher in people with depression (indicating diminished pain) although considerable study heterogeneity suggested little evidence of a generalized, uniform effect of depression; (2) Overall pain tolerance and pain ratings did not differ between depressed individuals and controls; and (3) The direction of the relationship between depression and pain appeared to be influenced by stimulus modality, with depressed individuals showing increased pain for ischemic stimulation, a reversal of the pattern found for other modalities.

Our findings of elevated overall pain threshold in depression confirm and extend preliminary findings from a previous meta-analysis of 6 experimental studies ${ }^{16}$, but in a much larger pool of 25 pain threshold studies. Small overall effect sizes were observed in both the current ( $\mathrm{g}=0.32$ ) and previous meta-analysis ( $\mathrm{d}=0.38)$. Additionally, we were able to examine a wider range of assessment measures than the previous review, including pain tolerance. Although there were fewer studies of tolerance available relative to threshold studies, there was little 
evidence of any link between depression and suprathreshold pain, with no significant differences in pain tolerance $(g=0.09)$ found. These findings suggest that depression may be associated with a general decreased sensitivity to low intensity stimulation, but not to higher intensity stimulation (e.g. that producing tolerance level of pain). The possibility of increased thresholds in depression is consistent with attentional pain processing models ${ }^{19}$. These state that limited attentional resources are competed for by painful and other, nonpainful stimuli. If greater attention is devoted to non-painful stimuli (e.g. environmental stimuli/internal thoughts), as has been observed in depression ${ }^{45}$, this should reduce pain by denying it attentional resources; especially for mild pain, which is of relatively low attentional priority. Dickens et al. ${ }^{16}$ pointed out that these models would explain the increased pain threshold they found in depressed participants, but should also predict little difference for higher intensity pain which commands greater attention. While the authors were unable to test this hypothesis due to lack of tolerance data, this hypothesis appears to be confirmed by our results which offer further support for current attentional models.

An important caveat in interpreting the association between depression and pain threshold is that considerable heterogeneity was observed. Studies varied both in the magnitude and direction of effects, suggesting that conclusions regarding a generalized effect of depression on pain perception are overly simplistic, and that any such effect may depend upon complex constellations of other moderating factors. Based on the current findings, diminished pain perception cannot be considered a reliable marker of depression.

A key finding was that the depression-pain link appears to be strongly influenced by the type of pain induced. Whereas depression was associated with reduced or no alteration of pain for most modalities (e.g., heat, cold, electrical), depressed participants exhibited increased pain in response to ischemic induction. These differences in responses across modalities are consistent with the wider pain literature exhibiting typically weak 
relationships of pain across different induction methods ${ }^{49}$. The relationship between other psychological variables, such as anxiety sensitivity, with pain have also been shown to vary across modality ${ }^{70}$. The fact that experimental studies frequently indicate decreased pain in depression contrasts with clinical studies, where depressed patients often report more pain complaints $^{2,15}$ with increased depression associated with increased pain severity ${ }^{35}$. Given that experimental and clinical pain differ on several key dimensions ${ }^{43}$ and are often weakly associated $^{12}$, it may be that experimental findings simply do not generalize outside of the laboratory. However, the fact that depression is associated with increased pain for ischemic (and clinical) pain but with decreased/unaltered pain for other inductions, could contribute to our understanding of the discrepancy between experimental and clinical findings. First, experimental studies typically rely on exteroceptive stimulation of the $\operatorname{skin}^{44}$ (the cold pressor also provides stimulation of both deeper and peripheral structures, although stimulation of deeper structures is far less pronounced, and several studies examined here used a skin contact thermode to induce cold). Both ischemia and clinical pain, however, are evoked through interoceptive pathways by nociceptors innervating deep structures ${ }^{57}$ (e.g. muscle, joints), involve greater C-fiber recruitment and are subject to greater modulation from descending pain inhibitory pathways ${ }^{57}$. Second, pain is a multidimensional experience involving sensory, cognitive and affective components ${ }^{43}$, and it may be that depressed individuals react more negatively to pain with a stronger affective component. Clinical pain is more distressing than typical experimental pain, and ischemic pain is often more severe, diffuse and uncontrollable than noxious skin stimulation ${ }^{43}$, so may produce greater negative affect (although too few studies recorded pain affect to evaluate this statistically). While the suggestion that the depression-pain link may be influenced by pain affect or its interoceptive/exteroceptive origin is necessarily speculative, it represents a plausible explanation for the discrepancies in findings across different modalities and clinical reports that warrant further empirical investigation. 
If any effects of depression are influenced by modality, pinpointing possible underlying mechanisms is largely speculative, given a lack of appropriate empirical data. One possible explanation is provided by Lautenbacher and Krieg's global theory of pain processing in psychiatric disorders ${ }^{37}$, and speculates that neurotransmitter dysfunction in depression affects pain perception in two ways. First, by diminishing spinal and subcortical processing which reduces processing of all sensory input therefore elevating sensory/pain thresholds. Second, by disrupting descending pain pathways which inhibit sustained or endogenous (e.g., ischemic) pain, thus heightening pain of endogenous origin. However, while there is some evidence that the areas of the brain involved in mood regulation also regulate pain pathways ${ }^{77}$, more empirical data are needed to convincingly demonstrate that depression selectively modulates pain processing in this way.

There is also tentative evidence to suggest that any putative effect of depression on pain could be influenced by anti-depressant medication. The two prospective studies found that the greater sensory and pain thresholds exhibited by depressed patients relative to controls were diminished following antidepressant treatment. In addition, the increased pain threshold observed in depressed participants was significant only in the unmedicated and not in the anti-depressant medicated group. However, given the minimal difference in effect size and the greater power of the unmedicated analysis from more available studies, this finding must be considered entirely preliminary. Nevertheless, since several neurotransmitters believed to be involved in the pathophysiology of depression are also involved in pain, e.g. serotonin, noradrenalin ${ }^{2}$, it would perhaps be unsurprising that modulation of these neurotransmitters might restore not only mood but also sensory/pain threshold gating. Further data is, however, clearly needed to support any potential effect of anti-depressant medication. 
Several limitations of the current review should be noted. First, considerable study heterogeneity was observed which could not be resolved by study differences in symptom severity, gender, age or study quality. Given this heterogeneity, caution in interpreting findings must be applied, especially where confidence intervals are relatively broad. Additionally, although significant differences in effect size across stimulus modalities were observed, there is little evidence that modality offers any substantive resolution of this heterogeneity. It seems likely that important moderators of the relationship between depression and pain perception exist (e.g., methodological, use/non-use of chronic pain patients) but remain unidentified. Second, while factors such as the endogenous nature of ischemic pain represent one theoretically plausible reason for differences across ischemic and other stimuli, other confounding characteristics (e.g. stimulus duration) may offer alternative explanations for these differences. Third, fewer studies investigating pain tolerance $(k=10)$ were available for analysis compared to pain threshold $(k=25)$. The lack of significant overall tolerance differences is unlikely to be attributable to reduced power, however, as the aggregated tolerance sample was still large $(\mathrm{N}=375)$ and the effect size close to zero. Finally, only experimental pain studies were examined and therefore the current findings may have limited generalizability to clinical pain.

Further research should be conducted to help elucidate reasons for inconsistency across study findings and identify potential moderators, such as pain duration ${ }^{54}$ and negative pain affect ${ }^{30}$, which have been suggested to influence the relationship between depression and chronic pain. In addition, measurement and/or careful control of variables likely to differ across ischemic and other pain inductions (e.g., stimulus contact time and negative affect), could help explain why differences across modalities were observed. Additional studies employing within-group designs, where individual variability can be controlled, could directly compare ischemic and cutaneous pain inductions to provide further supporting evidence for 
the role of modality. Future studies should also attempt to improve study quality by striving to acquire representative samples for depressed and control participants (e.g. avoiding hospital controls) and providing clearer descriptions of recruitment procedures.

In summary, this is the largest and most comprehensive meta-analysis of experimental pain induction studies in individuals with depression to date and suggests two key findings. First, there is some evidence that depression may be associated with an overall reduced perceptual sensitivity to low, but not high intensity stimulation. However, this overall effect is relatively small and considerable variation in study findings indicates that diminished pain may only be evident under certain, partly unidentified conditions. Second, any putative impact of depression appears to be strongly influenced by modality, with depressed participants showing increased pain in response to ischemic stimulation, but reduced or unaltered pain perception in response to other stimulus modalities. This finding is consistent with theory proposing different neural pathways for interoceptive and cutaneous-based pain and suggests that depression could affect these pathways differentially. Overall, these findings provide support for a relationship between depression and pain, but indicate that this relationship is complex and deserves further research that pays particular attention to variability due to stimulus intensity and modality as well as additional moderating variables.

\section{Acknowledgements}

The authors would like to thank several anonymous reviewers for their detailed comments on earlier drafts of this manuscript. 


\section{References}

1. Adler G, Gattaz WF: Pain perception threshold in major depression. Biol Psychiatry 34:687-689, 1993

2. Bair MJ, Robinson RL, Katon W, Kroenke K: Depression and pain comorbidity: a literature review. Arch Intern Med 163:2433-2445, 2003

3. Bär KJ, Brehm S, Boettger MK, Boettger S, Wagner G, Sauer H: Pain perception in major depression depends on pain modality. Pain 117:97-103, 2005

4. Bär KJ, Greiner W, Letsch A, Köbele R, Sauer H: Influence of gender and hemispheric lateralization on heat pain perception in major depression. $\mathbf{J}$ Psychiatr Res 37:345-353, 2003

5. Bär KJ, Terhaar J, Boettger MK, Boettger S, Berger S, Weiss T: Pseudohypoalgesia on the skin: a novel view on the paradox of pain perception in depression. J Clin Psychopharmacol 31:103-107, 2011

6. Bär KJ, Wagner G, Koschke M, Boettger S, Boettger MK, Schlösser R, Sauer $\mathrm{H}$ : Increased prefrontal activation during pain perception in major depression. Biol Psychiatry 62:1281-1287, 2007

7. Beck AT, Ward CH, Mendelson M, Mock J, Erbaugh J: An inventory for measuring depression. Arch Gen Psychiatry 4:561-571, 1961

8. Begg CB, Mazumdar M: Operating characteristics of a rank correlation test for publication bias. Biometrics 50:1088-1101, 1994

9. Ben-Tovim DI, Schwartz MS: Hypoalgesia in depressive illness. Br J Psychiatry 138:37-39, 1981

10. Boettger MK, Greiner W, Rachow T, Brühl C, Bär KJ: Sympathetic skin response following painful electrical stimulation is increased in major depression. Pain 149:130-134, 2010

11. Borenstein M, Hedges L, Higgins J, Rothstein HR. Introduction to MetaAnalysis. West Sussex: Wiley; 2009.

12. Boureau F, Luu M, Doubrère JF: Study of experimental pain measures and nociceptive reflex in chronic pain patients and normal subjects. Pain 44:131138,1991

13. Bridges KW, Goldberg DP: Somatic presentation of DSM III psychiatric disorders in primary care. J Psychosom Res 29:563-569, 1985

14. Davis GC, Buchsbaum MS, Bunney WE: Analgesia to painful stimuli in affective illness. Am J Psychiatry 136:1148-1151, 1979

15. Demyttenaere K, Bonnewyn A, Bruffaerts R, Brugha T, De Graaf R, Alonso J: Comorbid painful physical symptoms and depression: prevalence, work loss, and help seeking. J Affect Disord 92:185-193, 2006

16. Dickens C, McGowan L, Dale S: Impact of depression on experimental pain perception: a systematic review of the literature with meta-analysis. Psychosom Med 65:369-375, 2003

17. Duval S, Tweedie R: Trim and fill: A simple funnel-plot-based method of testing and adjusting for publication bias in meta-analysis. Biometrics 56:455463, 2000

18. Dworkin RH, Clark WC, Lipsitz JD: Pain responsivity in major depression and bipolar disorder. Psychiatry Res 56:173-181, 1995

19. Eccleston C, Crombez G: Pain demands attention: a cognitive-affective model of the interruptive function of pain. Psychol Bull 125:356-366, 1999 
20. Egger M, Davey Smith G, Schneider M, Minder C: Bias in meta-analysis detected by a simple, graphical test. BMJ 315:629-634, 1997

21. Euteneuer F, Schwarz MJ, Hennings A, Riemer S, Stapf T, Selberdinger V, Rief W: Depression, cytokines and experimental pain: evidence for sex-related association patterns. J Affect Disord 131:143-149, 2011

22. Fields HL: Pain modulation: expectation, opioid analgesia and virtual pain. Prog Brain Res 122:245-253, 2000

23. Fillingim RB, Girdler S, Booker DK, Light KC, Harris MB, Maixner W: Pain Sensitivity in Women with Premenstrual Dysphoric Disorder: A Preliminary Report. Journal of Women's Health 4:367-374, 1995

24. Fishbain DA, Cole B, Lewis JE, Gao J: Does pain interfere with antidepressant depression treatment response and remission in patients with depression and pain? An evidence-based structured review. Pain Med 15:1522-1539, 2014

25. Gracely RH 2005. In Melzack R, Wall P, eds, Textbook of pain, p. 267. Elsevier, London.

26. Hamilton M: A rating scale for depression. J Neurol Neurosurg Psychiatry 23:56-62, 1960

27. Han C, Pae CU: Pain and depression: a neurobiological perspective of their relationship. Psychiatry Investig 12:1-8, 2015

28. Higgins JP, Thompson SG, Deeks JJ, Altman DG: Measuring inconsistency in meta-analyses. BMJ 327:557-560, 2003

29. Higgins JPT, Green S. Cochrane Handbook for Systematic Reviews of Interventions. West Sussex: Wiley; 2008.

30. Hirsch JK, Sirois FM, Molnar D, Chang EC: Pain and Depressive Symptoms in Primary Care: Moderating Role of Positive and Negative Affect. Clin J Pain 32:562-567, 2016

31. Katon W, Sullivan MD: Depression and chronic medical illness. J Clin Psychiatry 51 Suppl:3-11; discussion 12, 1990

32. Kirmayer LJ, Robbins JM, Dworkind M, Yaffe MJ: Somatization and the recognition of depression and anxiety in primary care. Am J Psychiatry 150:734-741, 1993

33. Klatzkin RR, Lindgren ME, Forneris CA, Girdler SS: Histories of major depression and premenstrual dysphoric disorder: Evidence for phenotypic differences. Biol Psychol 84:235-247, 2010

34. Klauenberg S, Maier C, Assion HJ, Hoffmann A, Krumova EK, Magerl W, Scherens A, Treede RD, Juckel G: Depression and changed pain perception: hints for a central disinhibition mechanism. Pain 140:332-343, 2008

35. Kroenke K, Spitzer RL, Williams JB, Linzer M, Hahn SR, deGruy FV, Brody D: Physical symptoms in primary care. Predictors of psychiatric disorders and functional impairment. Arch Fam Med 3:774-779, 1994

36. Landis JR, Koch GG: The measurement of observer agreement for categorical data. Biometrics 33:159-174, 1977

37. Lautenbacher S, Krieg JC: Pain perception in psychiatric disorders: a review of the literature. J Psychiatr Res 28:109-122, 1994

38. Lautenbacher S, Roscher S, Strian D, Fassbender K, Krumrey K, Krieg JC: Pain perception in depression: relationships to symptomatology and naloxonesensitive mechanisms. Psychosom Med 56:345-352, 1994

39. Lautenbacher S, Spernal J, Schreiber W, Krieg JC: Relationship between clinical pain complaints and pain sensitivity in patients with depression and panic disorder. Psychosom Med 61:822-827, 1999 
40. Leino P, Magni G: Depressive and distress symptoms as predictors of low back pain, neck-shoulder pain, and other musculoskeletal morbidity: a 10-year follow-up of metal industry employees. Pain 53:89-94, 1993

41. López-Solà M, Pujol J, Hernández-Ribas R, Harrison BJ, Contreras-Rodríguez O, Soriano-Mas C, Deus J, Ortiz H, Menchón JM, Vallejo J, Cardoner N: Effects of duloxetine treatment on brain response to painful stimulation in major depressive disorder. Neuropsychopharmacology 35:2305-2317, 2010

42. Marazziti D, Castrogiovanni P, Rossi A, Rosa C, Ghione S, Di Muro A, Panattoni E, Cassano GB: Pain threshold is reduced in depression. Int $\mathrm{J}$ Neuropsychopharmacol 1:45-48, 1998

43. Melzack R, Wall P. Textbook of pain. London: Elsevier; 2005.

44. Meyer RA, Ringkamp M, Campbell JN, Raja SN 2005. In Melzack R, Wall P, eds, Textbook of pain, Elsevier, London.

45. Mialet JP, Pope HG, Yurgelun-Todd D: Impaired attention in depressive states: a non-specific deficit. Psychol Med 26:1009-1020, 1996

46. Mitchell AJ, Vaze A, Rao S: Clinical diagnosis of depression in primary care: a meta-analysis. Lancet 374:609-619, 2009

47. Moher D, Liberati A, Tetzlaff J, Altman DG, PRISMA G: Preferred reporting items for systematic reviews and meta-analyses: the PRISMA statement. BMJ 339:b2535, 2009

48. Muhtz C, Rodriguez-Raecke R, Hinkelmann K, Moeller-Bertram T, Kiefer F, Wiedemann K, May A, Otte C: Cortisol response to experimental pain in patients with chronic low back pain and patients with major depression. Pain Med 14:498-503, 2013

49. Neziri AY, Curatolo M, Nüesch E, Scaramozzino P, Andersen OK, ArendtNielsen L, Jüni P: Factor analysis of responses to thermal, electrical, and mechanical painful stimuli supports the importance of multi-modal pain assessment. Pain 152:1146-1155, 2011

50. Normand E, Potvin S, Gaumond I, Cloutier G, Corbin JF, Marchand S: Pain inhibition is deficient in chronic widespread pain but normal in major depressive disorder. J Clin Psychiatry 72:219-224, 2011

51. Otto MW, Dougher MJ, Yeo RA: Depression, pain, and hemispheric activation. J Nerv Ment Dis 177:210-218, 1989

52. Piñerua-Shuhaibar L, Prieto-Rincon D, Ferrer A, Bonilla E, Maixner W, SuarezRoca H: Reduced tolerance and cardiovascular response to ischemic pain in minor depression. J Affect Disord 56:119-126, 1999

53. Pinheiro MB, Ferreira ML, Refshauge K, Ordoñana JR, Machado GC, Prado LR, Maher CG, Ferreira PH: Symptoms of depression and risk of new episodes of low back pain. A systematic review and meta-analysis. Arthritis Care Res (Hoboken) 67:1591-1603, 2015

54. Probst T, Neumeier S, Altmeppen J, Angerer M, Loew T, Pieh C: Depressed Mood Differentially Mediates the Relationship between Pain Intensity and Pain Disability Depending on Pain Duration: A Moderated Mediation Analysis in Chronic Pain Patients. Pain Research and Management 2016:1-7, 2016

55. Rijavec N, Grubic VN: Depression and pain: often together but still a clinical challenge: a review. Psychiatr Danub 24:346-352, 2012

56. Rodriguez-Raecke R, Ihle K, Ritter C, Muhtz C, Otte C, May A: Neuronal differences between chronic low back pain and depression regarding long-term habituation to pain. Eur J Pain 18:701-711, 2014

57. Schaible H-G 2005. In Melzack R, Wall P, eds, Textbook of pain, Elsevier, 


\section{London.}

58. Schwier C, Kliem A, Boettger MK, Bär KJ: Increased cold-pain thresholds in major depression. J Pain 11:287-290, 2010

59. Simon GE, VonKorff M, Piccinelli M, Fullerton C, Ormel J: An international study of the relation between somatic symptoms and depression. N Engl J Med 341:1329-1335, 1999

60. Spernal J, Krieg JC, Lautenbacher S: Pain thresholds as a putative functional test for cerebral laterality in major depressive disorder and panic disorder. Neuropsychobiology 48:146-151, 2003

61. Strigo IA, Matthews SC, Simmons AN: Right anterior insula hypoactivity during anticipation of homeostatic shifts in major depressive disorder. Psychosom Med 72:316-323, 2010

62. Strigo IA, Simmons AN, Matthews SC, Craig AD, Paulus MP: Increased affective bias revealed using experimental graded heat stimuli in young depressed adults: evidence of "emotional allodynia". Psychosom Med 70:338344, 2008

63. Strigo IA, Simmons AN, Matthews SC, Craig AD, Paulus MP: Major Depressive Disorder is associated with altered functional brain response during anticipation and processing of heat pain. Arch Gen Psychiatry 65:1275-1284, 2008

64. Stroup DF, Berlin JA, Morton SC, Olkin I, Williamson GD, Rennie D, Moher D, Becker BJ, Sipe TA, Thacker SB: Meta-analysis of observational studies in epidemiology: a proposal for reporting. Meta-analysis Of Observational Studies in Epidemiology (MOOSE) group. JAMA 283:2008-2012, 2000

65. Stubbs B, Thompson T, Acaster S, Vancampfort D, Gaughran F, Correll CU: Decreased pain sensitivity among people with schizophrenia: a meta-analysis of experimental pain induction studies. Pain 156:2121-2131, 2015

66. Stubbs B, Thompson T, Solmi M, Vancampfort D, Sergi G, Luchini C, Veronese N: Is pain sensitivity altered in people with Alzheimer's disease? A systematic review and meta-analysis of experimental pain research. Exp Gerontol 82:30-38, 2016

67. Suarez-Roca H, Piñerua-Shuhaibar L, Morales ME, Maixner W: Increased perception of post-ischemic paresthesias in depressed subjects. J Psychosom Res 55:253-257, 2003

68. Terhaar J, Boettger MK, Schwier C, Wagner G, Israel AK, Bär KJ: Increased sensitivity to heat pain after sad mood induction in female patients with major depression. Eur J Pain 14:559-563, 2010

69. Terhaar J, Viola FC, Franz M, Berger S, Bär KJ, Weiss T: Differential processing of laser stimuli by $\mathrm{A} \delta$ and $\mathrm{C}$ fibres in major depression. Pain 152:1796-1802, 2011

70. Thompson T, Keogh E, French CC, Davis R: Anxiety sensitivity and pain: generalisability across noxious stimuli. Pain 134:187-196, 2008

71. Trivedi MH: The link between depression and physical symptoms. Prim Care Companion J Clin Psychiatry 6:12-16, 2004

72. von Knorring L, Espvall M: Experimentally induced pain in patients with depressive disorders. Acta Psychiatr Scand Suppl 255:121-133, 1974

73. Vos T, Barber RM, Bell B, Bertozzi-Villa A, Biryukov S, Bolliger I, Charlson F, Davis A, Degenhardt L, Dicker D, Duan L, Erskine H, Feigin VL, Ferrari AJ: Global, regional, and national incidence, prevalence, and years lived with disability for 301 acute and chronic diseases and injuries in 188 countries, 1990- 
2013: a systematic analysis for the Global Burden of Disease Study 2013. Lancet 386:743-800, 2015

74. Wells GA, Shea B, O'Connell D, Peterson J, Welch V, Losos M, Tugwell P: The Newcastle-Ottawa Scale (NOS) for assessing the quality of nonrandomised studies in meta-analyses. 2015

75. Wolff B 1984. In Wall PD, Melzack R, eds, Textbook of pain, p. 186. Churchill Livingstone, Edinburgh.

76. Zambito Marsala S, Pistacchi M, Tocco P, Gioulis M, Fabris F, Brigo F, Tinazzi M: Pain perception in major depressive disorder: A neurophysiological casecontrol study. Journal of the Neurological Sciences 2015

77. Zhang L, Zhang Y, Zhao ZQ: Anterior cingulate cortex contributes to the descending facilitatory modulation of pain via dorsal reticular nucleus. Eur $\mathrm{J}$ Neurosci 22:1141-1148, 2005 
Figure 1. Prisma flow diagram

Figure 2. Pain threshold in depressed vs. control participants

Figure S1. Pain tolerance in depressed vs. control participants

Figure S2. Sensory threshold in depressed vs. control participants 
Table 1. Summary of included studies

\begin{tabular}{|c|c|c|c|c|c|c|c|}
\hline Author & $\begin{array}{l}\text { Location \& } \\
\text { Setting }\end{array}$ & Depression group & $\begin{array}{l}\text { Antidepressant } \\
\text { Treatment }\end{array}$ & $\begin{array}{l}\text { Control } \\
\text { participants }\end{array}$ & $\begin{array}{l}\text { Pain } \\
\text { modality }\end{array}$ & Pain measure & $\begin{array}{l}\text { NOS } \\
\text { scores }\end{array}$ \\
\hline $\begin{array}{l}\text { Zambito } \\
\text { Marsala et al } \\
2015^{76}\end{array}$ & $\begin{array}{l}\text { Italy, setting } \\
\text { not stated }\end{array}$ & $\begin{array}{l}\mathrm{N}=27, \mathrm{MDD}, 26 \% \text { female, } \\
\text { age=47.2 years, HAM-D: } 22.6 . \\
\text { Pain screening }{ }^{c}=\text { yes }\end{array}$ & Unmedicated & $\begin{array}{l}\mathrm{N}=27,26 \% \\
\text { female, age }=53.7\end{array}$ & Electrical & $\begin{array}{l}\text { Sensory threshold } \\
\text { Pain threshold } \\
\text { Pain tolerance }\end{array}$ & 5 \\
\hline $\begin{array}{l}\text { Rodriguez- } \\
\text { Raecke et al } \\
2014^{a, 56}\end{array}$ & $\begin{array}{l}\text { Germany, } \\
\text { inpatient }\end{array}$ & $\begin{array}{l}\mathrm{N}=21, \mathrm{MDD}, 38 \% \text { female, } \\
\text { age=36.1 years. Pain screening } \\
=\text { yes }\end{array}$ & Mixed & $\begin{array}{l}\mathrm{N}=21,71 \% \\
\text { female, age }=36.8\end{array}$ & Heat & $\begin{array}{l}\text { Pain threshold } \\
\text { fMRI }\end{array}$ & 6 \\
\hline $\begin{array}{l}\text { Muhtz et al } \\
2013^{a, 48}\end{array}$ & $\begin{array}{l}\text { Germany, } \\
\text { inpatient }\end{array}$ & $\begin{array}{l}\mathrm{N}=22, \mathrm{MDD}, 27 \% \text { female, } \\
\text { age }=36.3 \text { years. Pain screening } \\
=\text { yes }\end{array}$ & Mixed & $\begin{array}{l}\mathrm{N}=33,64 \% \\
\text { female, age }=33.3\end{array}$ & Heat & Intensity rating & 6 \\
\hline Bär et al $2011^{5}$ & $\begin{array}{l}\text { Germany, } \\
\text { setting not } \\
\text { stated }\end{array}$ & $\begin{array}{l}\mathrm{N}=22, \mathrm{MDD}, 77 \% \text { female, } \\
\text { age=42.2 years, Baseline } \\
\text { MADRS: } 25.36, \mathrm{BDI}: 22.5 ; 6 \\
\text { weeks: MADRS: } 9.41, \mathrm{BDI}: \\
\text { 11.36. Participants scoring >3 } \\
\text { on present pain excluded }\end{array}$ & $\begin{array}{l}\text { Unmedicated/ } \\
\text { Medicated } \\
\text { (Duloxetine) }\end{array}$ & $\begin{array}{l}\mathrm{N}=22,77 \% \\
\text { female, age }=42.5\end{array}$ & $\begin{array}{l}\text { Heat } \\
\text { Ischemic }\end{array}$ & $\begin{array}{l}\text { Sensory threshold } \\
\text { Pain threshold } \\
\text { Pain tolerance } \\
\text { Intensity rating }\end{array}$ & 6 \\
\hline $\begin{array}{l}\text { Normand et al } \\
2011^{50}\end{array}$ & $\begin{array}{l}\text { Canada, } \\
\text { setting not } \\
\text { stated }\end{array}$ & $\begin{array}{l}\mathrm{N}=26, \mathrm{MDD}, 61 \% \text { female, } \\
\text { age }=46.5 \text { years. Pain screening } \\
=\text { yes }\end{array}$ & Medicated & $\begin{array}{l}\mathrm{N}=40,60 \% \\
\text { female, age }=45.2\end{array}$ & $\begin{array}{l}\text { Heat } \\
\text { Cold }\end{array}$ & $\begin{array}{l}\text { Pain threshold } \\
\text { Intensity rating }\end{array}$ & 5 \\
\hline $\begin{array}{l}\text { Terhaar et al } \\
2011^{69}\end{array}$ & $\begin{array}{l}\text { Germany, } \\
\text { inpatient }\end{array}$ & $\begin{array}{l}\mathrm{N}=27, \mathrm{MDD}, 78 \% \text { female, } \\
\text { age }=38.5 \text { years, BDI: } 23, \mathrm{HAM}- \\
\mathrm{D}: 23.2 . \text { Pain screening }=y e s\end{array}$ & Unmedicated & $\begin{array}{l}\mathrm{N}=27,78 \% \\
\text { female, age }=39.5\end{array}$ & Laser & $\begin{array}{l}\text { Sensory threshold } \\
\text { Pain threshold }\end{array}$ & 5 \\
\hline $\begin{array}{l}\text { Euteneuer et al } \\
2011^{21}\end{array}$ & $\begin{array}{l}\text { Germany, } \\
\text { outpatient }\end{array}$ & $\begin{array}{l}\mathrm{N}=37, \mathrm{MDD}, 56.7 \% \text { female, } \\
\text { age=33.5 years, BDI: } 21.46, \mathrm{SCL} \\
\text { 90-R GSI: 1.03. Pain screening } \\
=\text { yes }\end{array}$ & Mixed & $\begin{array}{l}\mathrm{N}=48,63 \% \\
\text { female, age }=35.8\end{array}$ & Pressure & Pain threshold & 4 \\
\hline $\begin{array}{l}\text { Strigo et al } \\
2010^{61}\end{array}$ & $\begin{array}{l}\text { US, setting } \\
\text { not stated }\end{array}$ & $\begin{array}{l}\mathrm{N}=15, \mathrm{MDD}, 80 \% \text { female, } \\
\text { age=24.5 years, BDI-2: } 27.8 . \\
\text { Pain screening =yes }\end{array}$ & Unmedicated & $\begin{array}{l}\mathrm{N}=17,59 \% \\
\text { female, age }=24.3\end{array}$ & Heat & $\begin{array}{l}\text { Pain threshold (for } \\
\text { 'moderate' pain) }\end{array}$ & 5 \\
\hline
\end{tabular}




\begin{tabular}{|c|c|c|c|c|c|c|c|}
\hline Author & $\begin{array}{l}\text { Location \& } \\
\text { Setting }\end{array}$ & Depression group & $\begin{array}{l}\text { Antidepressant } \\
\text { Treatment }\end{array}$ & $\begin{array}{l}\text { Control } \\
\text { participants }\end{array}$ & $\begin{array}{l}\text { Pain } \\
\text { modality }\end{array}$ & Pain measure & $\begin{array}{l}\text { NOS } \\
\text { scores }\end{array}$ \\
\hline $\begin{array}{l}\text { Klatzkin et al } \\
2010^{33}\end{array}$ & $\begin{array}{l}\text { US, setting } \\
\text { not stated }\end{array}$ & $\begin{array}{l}\mathrm{N}=10, \mathrm{PMDD}, 100 \% \text { female, } \\
\text { age not stated. Pain screening } \\
=\text { yes }\end{array}$ & Unmedicated & $\begin{array}{l}\mathrm{N}=18,100 \% \\
\text { female, age not } \\
\text { stated }\end{array}$ & $\begin{array}{l}\text { Cold pressor } \\
\text { Ischemic }\end{array}$ & $\begin{array}{l}\text { Pain threshold } \\
\text { Pain tolerance } \\
\text { Intensity rating } \\
\text { Unpleasantness }\end{array}$ & 5 \\
\hline $\begin{array}{l}\text { Lopez-Sola et al } \\
2010^{41}\end{array}$ & $\begin{array}{l}\text { Spain, setting } \\
\text { not stated }\end{array}$ & $\begin{array}{l}\mathrm{N}=13, \mathrm{MDD}, 85 \% \text { female, } \\
\text { age=44.6 years, HAM-D: } 21.3, \\
\text { Pain screening =yes }\end{array}$ & Medicated & $\begin{array}{l}\mathrm{N}=20,75 \% \\
\text { female, age }=47.2\end{array}$ & Heat & $\begin{array}{l}\text { Intensity } \\
\text { Unpleasantness } \\
\text { fMRI }\end{array}$ & 5 \\
\hline $\begin{array}{l}\text { Boettger et al } \\
2010^{10}\end{array}$ & $\begin{array}{l}\text { Germany, } \\
\text { inpatient }\end{array}$ & $\begin{array}{l}\mathrm{N}=22, \mathrm{MDD}, \% \text { female not } \\
\text { stated, age=41 years, BDI: } \\
\text { 24.2, HAM-D: } 23.0 . \text { Pain } \\
\text { screening =not stated }\end{array}$ & Mixed & $\begin{array}{l}\mathrm{N}=20, \% \text { female } \\
\text { not stated, } \\
\text { age }=40\end{array}$ & Electrical & $\begin{array}{l}\text { Intensity rating } \\
\text { EEG }\end{array}$ & 5 \\
\hline $\begin{array}{l}\text { Terhaar et al } \\
2010^{68}\end{array}$ & $\begin{array}{l}\text { Germany, } \\
\text { inpatient }\end{array}$ & $\begin{array}{l}\mathrm{N}=25, \mathrm{MDD}, 100 \% \text { female, } \\
\text { age }=49.8 \text { years, } \mathrm{BDI}: 18.8, \\
\text { MADRS: } 21.7 . \text { Pain ratings }>2 \\
\text { was exclusion criterion }\end{array}$ & Mixed & $\begin{array}{l}\mathrm{N}=25,100 \% \\
\text { female, age }=48.3\end{array}$ & Heat & Pain threshold & 5 \\
\hline $\begin{array}{l}\text { Schwier et al } \\
2010^{58}\end{array}$ & $\begin{array}{l}\text { Germany, } \\
\text { setting not } \\
\text { stated }\end{array}$ & $\begin{array}{l}\mathrm{N}=20, \mathrm{MDD}, 85 \% \text { female, } \\
\text { age=37.2 years, HAM-D: } 19.4 \text {, } \\
\text { BDI: } 24.3 . \text { Pain screening =yes }\end{array}$ & Unmedicated & $\begin{array}{l}\mathrm{N}=20,85 \% \\
\text { female, age }=34.8\end{array}$ & Cold & Pain threshold & 5 \\
\hline $\begin{array}{l}\text { Strigo et al } \\
2008^{b, 62}\end{array}$ & $\begin{array}{l}\text { US, setting } \\
\text { not stated }\end{array}$ & $\begin{array}{l}\mathrm{N}=15, \mathrm{MDD}, 80 \% \text { female, } \\
\text { age=24.5 years, BDI: } 27.8 \text {. Pain } \\
\text { screening =yes }\end{array}$ & Unmedicated & $\begin{array}{l}\mathrm{N}=15,80 \% \\
\text { female, age }=23.9\end{array}$ & Heat & $\begin{array}{l}\text { Pain threshold } \\
\text { Intensity rating } \\
\text { Unpleasantness rating }\end{array}$ & 6 \\
\hline $\begin{array}{l}\text { Strigo et al } \\
2008^{\text {b, } 63}\end{array}$ & $\begin{array}{l}\text { US, setting } \\
\text { not stated }\end{array}$ & $\begin{array}{l}\mathrm{N}=15, \mathrm{MDD}, 80 \% \text { female, } \\
\text { age=24.5 years, BDI: } 27.8 \text {. Pain } \\
\text { screening =yes }\end{array}$ & Unmedicated & $\begin{array}{l}\mathrm{N}=15,67 \% \\
\text { female, age }=24.3\end{array}$ & Heat & fMRI & 5 \\
\hline $\begin{array}{l}\text { Klauenberg et al } \\
2008^{34}\end{array}$ & $\begin{array}{l}\text { Germany, } \\
\text { inpatient }\end{array}$ & $\begin{array}{l}\mathrm{N}=25 \text {, Mixed diagnosis types, } \\
60 \% \text { female, age }=48 \text { years, } \\
\text { HADS (depression): } 13, \text { HADS } \\
\text { (anxiety): } 13 . \text { Pain screening } \\
=\text { not stated }\end{array}$ & Medicated & $\begin{array}{l}\mathrm{N}=25,67 \% \\
\text { female, age=47. }\end{array}$ & $\begin{array}{l}\text { Cold } \\
\text { Heat } \\
\text { Mechanical } \\
\text { (von Frey) } \\
\text { Mechanical } \\
\text { (pressure) }\end{array}$ & $\begin{array}{l}\text { Sensory threshold } \\
\text { Pain threshold } \\
\text { Intensity rating }\end{array}$ & 5 \\
\hline
\end{tabular}




\begin{tabular}{|c|c|c|c|c|c|c|c|}
\hline Author & $\begin{array}{l}\text { Location \& } \\
\text { Setting }\end{array}$ & Depression group & $\begin{array}{l}\text { Antidepressant } \\
\text { Treatment }\end{array}$ & $\begin{array}{l}\text { Control } \\
\text { participants }\end{array}$ & $\begin{array}{l}\text { Pain } \\
\text { modality }\end{array}$ & Pain measure & $\begin{array}{l}\text { NOS } \\
\text { scores }\end{array}$ \\
\hline Bär et al $2007^{6}$ & $\begin{array}{l}\text { Germany, } \\
\text { inpatient }\end{array}$ & $\begin{array}{l}\mathrm{N}=13, \mathrm{MDD}, 100 \% \text { female, } \\
\text { age=35.9 years, HAM-D: } 23.7 \text {, } \\
\mathrm{BDI}: 26.5, \mathrm{STAI}-\mathrm{X} 1: 42.0, \mathrm{STAl}- \\
\mathrm{X} 2: 46.1 . \text { Pain screening: all } \\
\text { participants pain ratings<2 }\end{array}$ & Unmedicated & $\begin{array}{l}\mathrm{N}=13,100 \% \\
\text { female, } \\
\text { age=34.3. }\end{array}$ & Heat & $\begin{array}{l}\text { Pain threshold } \\
\text { fMRI }\end{array}$ & 5 \\
\hline Bär et al $2005^{3}$ & $\begin{array}{l}\text { Germany, } \\
\text { setting not } \\
\text { stated }\end{array}$ & $\begin{array}{l}\mathrm{N}=30, \mathrm{MDD}, 77 \% \text { female, } \\
\text { age }=44.9 \text { years, HAM-D: } 21.9 . \\
\text { Pain screening =yes }\end{array}$ & $\begin{array}{l}\text { Mixed (mostly } \\
\text { medicated) }\end{array}$ & $\begin{array}{l}\mathrm{N}=30,77 \% \\
\text { female, } \\
\text { age }=44.7 .\end{array}$ & $\begin{array}{l}\text { Heat } \\
\text { Electrical } \\
\text { Ischemic }\end{array}$ & $\begin{array}{l}\text { Pain threshold } \\
\text { Pain tolerance }\end{array}$ & 5 \\
\hline $\begin{array}{l}\text { Spernal et al } \\
2003^{60}\end{array}$ & $\begin{array}{l}\text { Germany, } \\
\text { inpatient }\end{array}$ & $\begin{array}{l}\mathrm{N}=21, \mathrm{MDD}, 57 \% \text { female, } \\
\text { age=39 years, HAM-D: } 23.6, \\
\text { HAM-A: } 21.2 . \text { Pain screening } \\
=\text { not stated }\end{array}$ & Unmedicated & $\begin{array}{l}\mathrm{N}=20,60 \% \\
\text { female, age }=34.6\end{array}$ & $\begin{array}{l}\text { Heat } \\
\text { Cold pressor } \\
\text { Pressure }\end{array}$ & Pain threshold & 5 \\
\hline $\begin{array}{l}\text { Suarez-Roca et } \\
\text { al } 2003^{67}\end{array}$ & $\begin{array}{l}\text { Venezuela, } \\
\text { setting not } \\
\text { stated }\end{array}$ & $\begin{array}{l}\mathrm{N}=11 \text {, Dysthymic, } 91 \% \text { female, } \\
\text { age=32.4 years, Zung's index: } \\
\text { 60. Pain screening =not stated }\end{array}$ & Not stated & $\begin{array}{l}\mathrm{N}=19,79 \% \\
\text { female, age }=31.4\end{array}$ & Ischemic & $\begin{array}{l}\text { Pain tolerance } \\
\text { Intensity rating }\end{array}$ & 5 \\
\hline Bär et al $2003^{4}$ & $\begin{array}{l}\text { Germany, } \\
\text { setting not } \\
\text { stated }\end{array}$ & $\begin{array}{l}\mathrm{N}=20, \mathrm{MDD}, 70 \% \text { female, } \\
\text { age=40.1 years, BDI: } 22.8, \\
\text { HAM-D: } 28.1 \text { Pain screening } \\
=\text { not stated }\end{array}$ & $\begin{array}{l}\text { Unmedicated/ } \\
\text { Medicated }\end{array}$ & $\begin{array}{l}\mathrm{N}=20,70 \% \\
\text { female, age }=38.8\end{array}$ & Heat & $\begin{array}{l}\text { Sensory threshold } \\
\text { Pain threshold } \\
\text { Pain tolerance }\end{array}$ & 6 \\
\hline $\begin{array}{l}\text { Lautenbacher et } \\
\text { al } 1999^{39}\end{array}$ & $\begin{array}{l}\text { Germany, } \\
\text { inpatient }\end{array}$ & $\begin{array}{l}\mathrm{N}=13, \mathrm{MDD}, 62 \% \text { female, } \\
\text { age=35.4 years, HAM-D: } 23.8, \\
\text { HAM-A: } 23.2 . \text { Pain screening } \\
=\text { not stated }\end{array}$ & Unmedicated & $\begin{array}{l}\mathrm{N}=13,62 \% \\
\text { female, age }=32.9\end{array}$ & $\begin{array}{l}\text { Pressure } \\
\text { Cold pressor } \\
\text { Heat }\end{array}$ & Pain threshold & 5 \\
\hline $\begin{array}{l}\text { Pinerua- } \\
\text { Shuhaibar et al } \\
1999^{52}\end{array}$ & $\begin{array}{l}\text { Venezuela, } \\
\text { setting not } \\
\text { stated }\end{array}$ & $\begin{array}{l}\mathrm{N}=11 \text {, Dysthymic, } 91 \% \text { female, } \\
\text { age=32 years, Zung: } 59 . \text { Pain } \\
\text { screening =not stated }\end{array}$ & Unmedicated & $\begin{array}{l}\mathrm{N}=32,47 \% \\
\text { female, age }=32\end{array}$ & Ischemic & $\begin{array}{l}\text { Pain threshold } \\
\text { Pain tolerance } \\
\text { Intensity rating } \\
\text { Unpleasantness rating }\end{array}$ & 4 \\
\hline $\begin{array}{l}\text { Marazziti et al } \\
1998^{42}\end{array}$ & $\begin{array}{l}\text { Italy, } \\
\text { Outpatient }\end{array}$ & $\begin{array}{l}\mathrm{N}=13, \mathrm{MDD}, 69 \% \text { female, } \\
\text { age=43.6 years, HAM-D: } 18.3 \text {, } \\
\text { SAD: } 71.2 . \text { Pain screening =not } \\
\text { stated }\end{array}$ & $\begin{array}{l}\text { Mixed (mostly } \\
\text { unmedicated) }\end{array}$ & $\begin{array}{l}\mathrm{N}=13,38 \% \\
\text { female, age }=30.7\end{array}$ & Electrical & $\begin{array}{l}\text { Sensory threshold } \\
\text { Pain tolerance }\end{array}$ & 4 \\
\hline
\end{tabular}




\begin{tabular}{|c|c|c|c|c|c|c|c|}
\hline Author & $\begin{array}{l}\text { Location \& } \\
\text { Setting }\end{array}$ & Depression group & $\begin{array}{l}\text { Antidepressant } \\
\text { Treatment }\end{array}$ & $\begin{array}{l}\text { Control } \\
\text { participants }\end{array}$ & $\begin{array}{l}\text { Pain } \\
\text { modality }\end{array}$ & Pain measure & $\begin{array}{l}\text { NOS } \\
\text { scores }\end{array}$ \\
\hline $\begin{array}{l}\text { Fillingim et al } \\
1995^{23}\end{array}$ & $\begin{array}{l}\text { US, setting } \\
\text { not stated }\end{array}$ & $\begin{array}{l}\mathrm{N}=7, \mathrm{PDD}, 100 \% \text { female, } \\
\text { age }=35.1 \text { years. Pain screening } \\
=\text { yes }\end{array}$ & Unmedicated & $\begin{array}{l}\mathrm{N}=11,100 \% \\
\text { female, age }=31.4\end{array}$ & $\begin{array}{l}\text { Heat } \\
\text { Ischemic }\end{array}$ & $\begin{array}{l}\text { Pain threshold } \\
\text { Pain tolerance }\end{array}$ & 5 \\
\hline $\begin{array}{l}\text { Dworkin et al } \\
1995^{18}\end{array}$ & US, Inpatient & $\begin{array}{l}\mathrm{N}=26, \mathrm{MDD}, 73 \% \text { female, } \\
\text { age }=42.4 \text { years. Pain screening } \\
=\text { not stated }\end{array}$ & Not stated & $\begin{array}{l}\mathrm{N}=32,50 \% \\
\text { female, age }=46.6\end{array}$ & Heat & Pain threshold & 5 \\
\hline $\begin{array}{l}\text { Lautenbacher et } \\
\text { al } 1994^{38}\end{array}$ & $\begin{array}{l}\text { Germany, } \\
\text { setting not } \\
\text { stated }\end{array}$ & $\begin{array}{l}\mathrm{N}=20, \mathrm{MDD}, 40 \% \text { female, } \\
\text { age=36.9 years, HAM-D: } 25.1 . \\
\text { Pain screening =not stated }\end{array}$ & Mixed & $\begin{array}{l}\mathrm{N}=20,40 \% \\
\text { female, age: } 36.2\end{array}$ & $\begin{array}{l}\text { Heat } \\
\text { Pressure }\end{array}$ & $\begin{array}{l}\text { Pain threshold } \\
\text { Sensory threshold }\end{array}$ & 5 \\
\hline Adler et al $1993^{1}$ & $\begin{array}{l}\text { Germany, } \\
\text { setting not } \\
\text { stated }\end{array}$ & $\begin{array}{l}\mathrm{N}=16, \mathrm{MDD}, 56 \% \text { female, } \\
\text { age=33.2 years, HAM-D: } 26.7 . \\
\text { Pain screening =not stated }\end{array}$ & Unmedicated & $\begin{array}{l}\mathrm{N}=16, \% \text { female } \\
\text { not stated, age } \\
\text { not stated }\end{array}$ & Electrical & $\begin{array}{l}\text { Sensory threshold } \\
\text { Pain threshold }\end{array}$ & 4 \\
\hline Otto et al $1989^{51}$ & $\begin{array}{l}\text { US, setting } \\
\text { n/a }\end{array}$ & $\begin{array}{l}\mathrm{N}=16, \mathrm{BDI}=>16 \text { (depression), } \\
\text { 100\% female, age not stated, } \\
\text { BDI: } 25.9 . \text { Pain screening =not } \\
\text { stated }\end{array}$ & Unmedicated & $\begin{array}{l}\mathrm{N}=16,100 \% \\
\text { female, age not } \\
\text { stated }\end{array}$ & Cold pressor & $\begin{array}{l}\text { Pain threshold } \\
\text { Pain tolerance } \\
\text { Intensity rating }\end{array}$ & 5 \\
\hline $\begin{array}{l}\text { Ben-Tovin et al } \\
1981^{9}\end{array}$ & $\begin{array}{l}\text { Location not } \\
\text { stated, } \\
\text { Inpatient }\end{array}$ & $\begin{array}{l}\mathrm{N}=8 \text {, Primary affective } \\
\text { disorder: depressed type, } \\
100 \% \text { female, age= } 59.7 \text { years, } \\
\text { HAM-D: } 18.8 . \text { Pain screening } \\
=\text { not stated }\end{array}$ & Medicated & $\begin{array}{l}\mathrm{N}=8,100 \% \\
\text { female, age }=37.2\end{array}$ & Electrical & $\begin{array}{l}\text { Sensory threshold } \\
\text { Pain threshold }\end{array}$ & 6 \\
\hline $\begin{array}{l}\text { Davis et al } \\
1979^{14}\end{array}$ & US, inpatient & $\begin{array}{l}\mathrm{N}=66 \text {, Depressed (Bunney- } \\
\text { Hamburg rating scale, global } \\
\text { mania }=>2 \text { ), } 61 \% \text { female, } \\
\text { age }=38 \text { years. Pain screening } \\
=\text { not stated }\end{array}$ & Unmedicated & $\begin{array}{l}\mathrm{N}=48,65 \% \\
\text { female, age }=38.2\end{array}$ & Electrical & $\begin{array}{l}\text { Pain threshold } \\
\text { Unpleasantness rating } \\
\text { EEG }\end{array}$ & 5 \\
\hline $\begin{array}{l}\text { von Knorring et } \\
\text { al } 1974^{72}\end{array}$ & $\begin{array}{l}\text { Sweden, } \\
\text { setting not } \\
\text { stated }\end{array}$ & $\begin{array}{l}\mathrm{N}=45 \text {, Depressive disorders, } \% \\
\text { female not stated, age not } \\
\text { stated. } \text { Pain screening =not } \\
\text { stated }\end{array}$ & Not stated & $\begin{array}{l}\mathrm{N}=20, \% \text { female } \\
\text { not stated, age } \\
\text { not stated }\end{array}$ & Electrical & $\begin{array}{l}\text { Pain threshold } \\
\text { Pain tolerance }\end{array}$ & 5 \\
\hline
\end{tabular}




\begin{tabular}{|c|c|c|c|c|c|c|c|}
\hline Author & $\begin{array}{l}\text { Location \& } \\
\text { Setting }\end{array}$ & Depression group & $\begin{array}{l}\text { Antidepressant } \\
\text { Treatment }\end{array}$ & $\begin{array}{l}\text { Control } \\
\text { participants }\end{array}$ & $\begin{array}{l}\text { Pain } \\
\text { modality }\end{array}$ & Pain measure & $\begin{array}{l}\text { NOS } \\
\text { scores }\end{array}$ \\
\hline TOTAL & $\begin{array}{l}\text { Studies }=32 \\
\text { (Unique=30); } \\
\text { Region: N } \\
\text { America }=8, \\
\text { Europe }=19, \\
\text { S America 2, } \\
\text { Not stated=1; } \\
\text { Setting: } \\
\text { Outpatient=2 } \\
\text { Inpatients=11, } \\
\text { Unclear }=17\end{array}$ & $\begin{array}{l}\mathrm{N}=641 \text { participants with } \\
\text { depression, mean age= } 39.3 \\
\text { years, females }=74.0 \% .17 \\
\text { studies screened for chronic } \\
\text { pain, } 15 \text { studies did not. }\end{array}$ & $\begin{array}{l}\text { Antidepressant- } \\
\text { treated=6; } \\
\text { Unmedicated=16; } \\
\text { Mixed = 7; Not } \\
\text { stated =3 }\end{array}$ & $\begin{array}{l}\mathrm{N}=676 \text { controls, } \\
\text { mean age }=38.0 \\
\text { years, } \\
\text { females }=71.4 \%\end{array}$ & $\begin{array}{l}\text { Heat=17; } \\
\text { Cold=7; } \\
\text { Pressure=4; } \\
\text { Ischemic=6; } \\
\text { Laser=1; } \\
\text { Electrical=8; } \\
\text { Mechanical=1 }\end{array}$ & $\begin{array}{l}\text { Pain threshold=26; } \\
\text { Pain intensity=11; } \\
\text { Pain tolerance=11; } \\
\text { Sensory threshold=9; } \\
\text { Pain unpleasantness=5; } \\
\text { fRMI=4; } \\
\text { EEG=2 }\end{array}$ & \\
\hline
\end{tabular}

Key: BDI: Beck Depression Inventory; EEG: Electroencephalography; HAM-A: Hamilton Anxiety Rating Scale; HAM-D: Hamilton Rating Scale for Depression; MADRS: Montgomery Asberg Depression Rating Scale; MDD: Major Depressive Disorder; PMDD: Premenstrual Dysphoric Disorder; SAD: Scala di

Autovalutazione per la Depressione; STAl: State-Trait Anxiety Inventory.

${ }^{a, b}$ Identical superscript symbol indicates same sample used across two studies (but different pain outcomes reported in each)

${ }^{c}$ Screening for chronic pain 
Table 2. Meta-analysis results of experimental pain in depression versus controls (positive Hedges $\mathrm{g}$ indicates reduced pain sensitivity in depression)

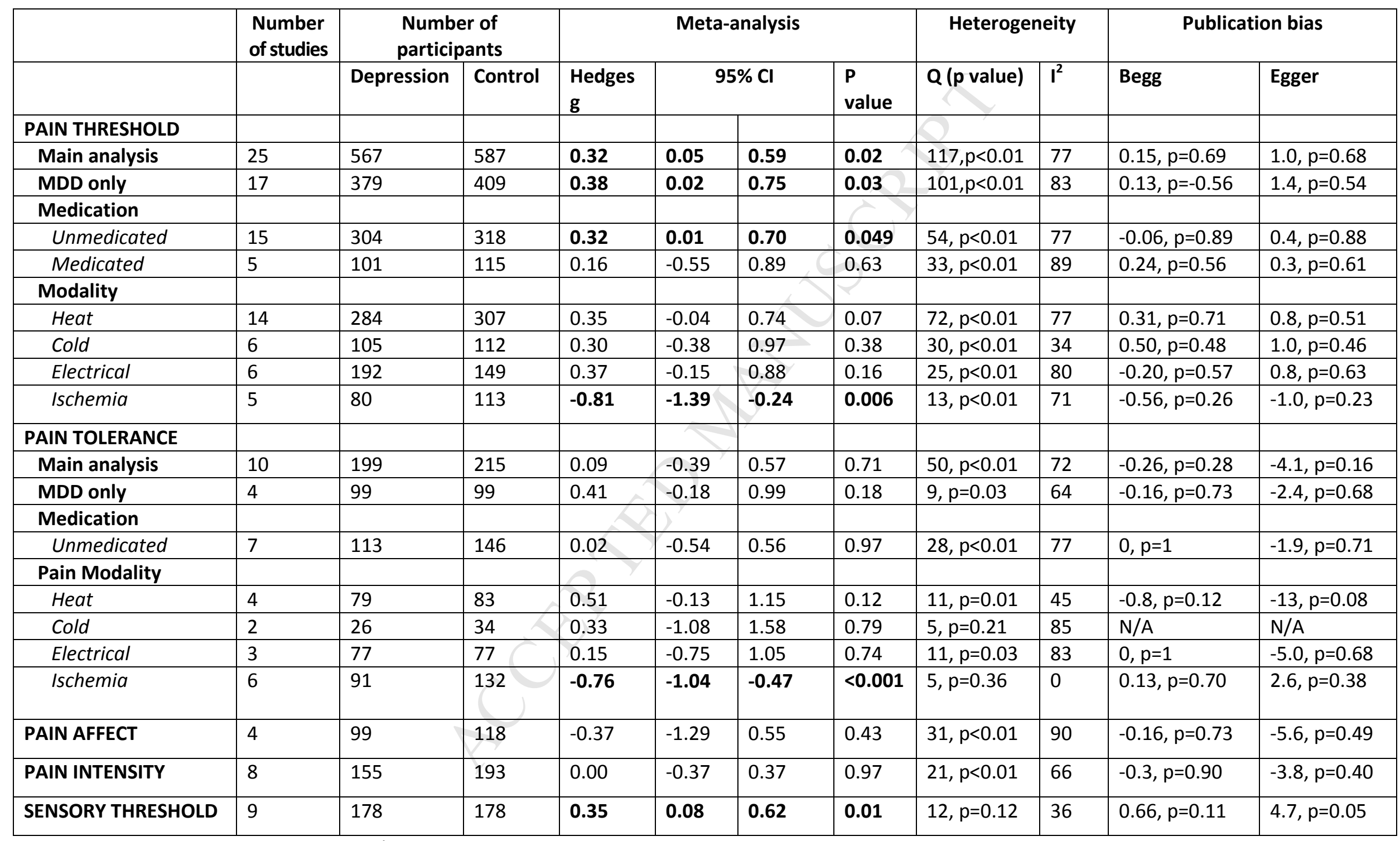

Key: $\mathrm{MDD}=$ major depressive disorder, $\mathrm{N} / \mathrm{A}=$ not applicable ( $<3$ studies publication bias not applicable).

Bolded values: significant effect size results 
Figure 1. PRISMA flow diagram
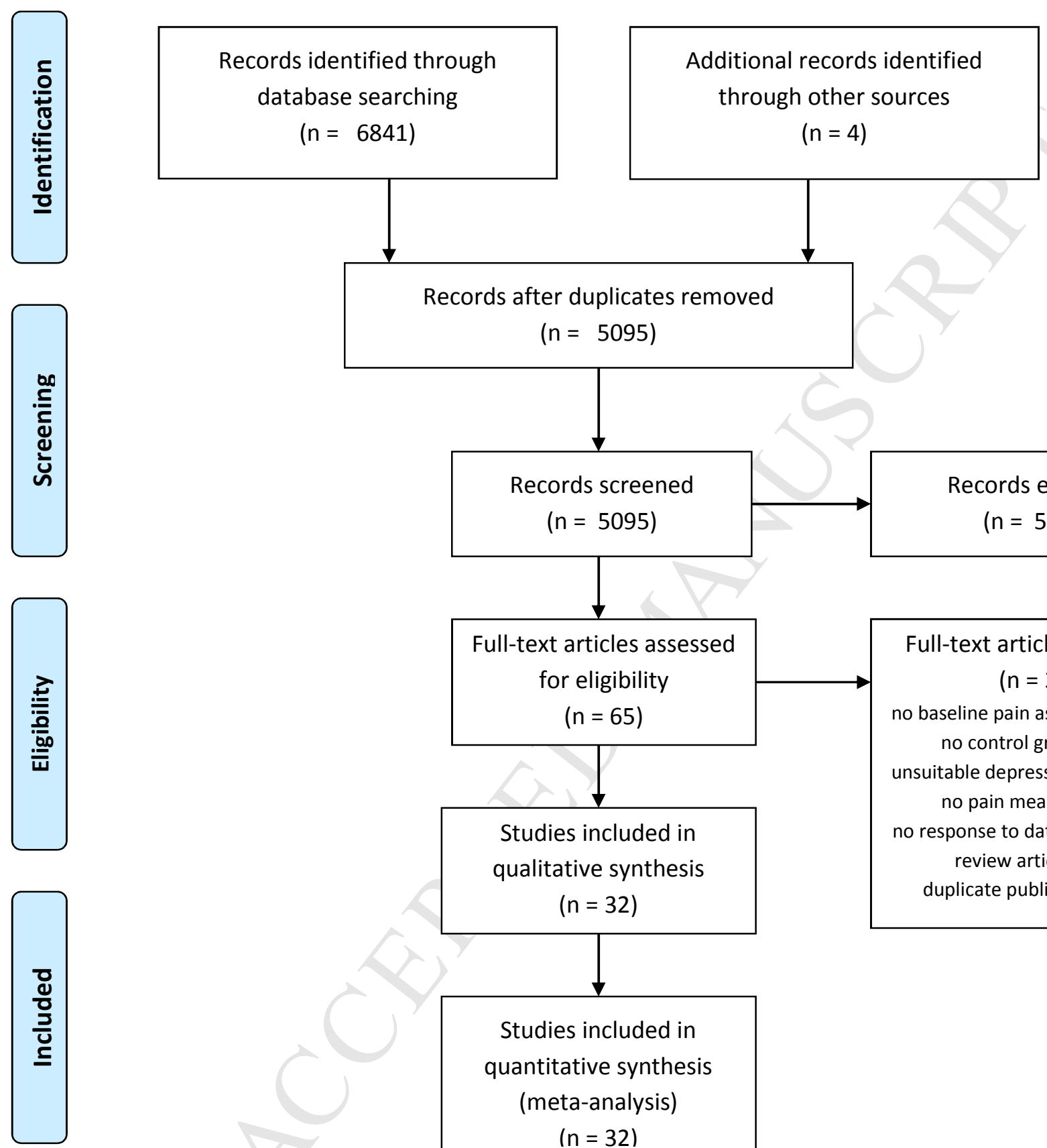

$(n=5095)$
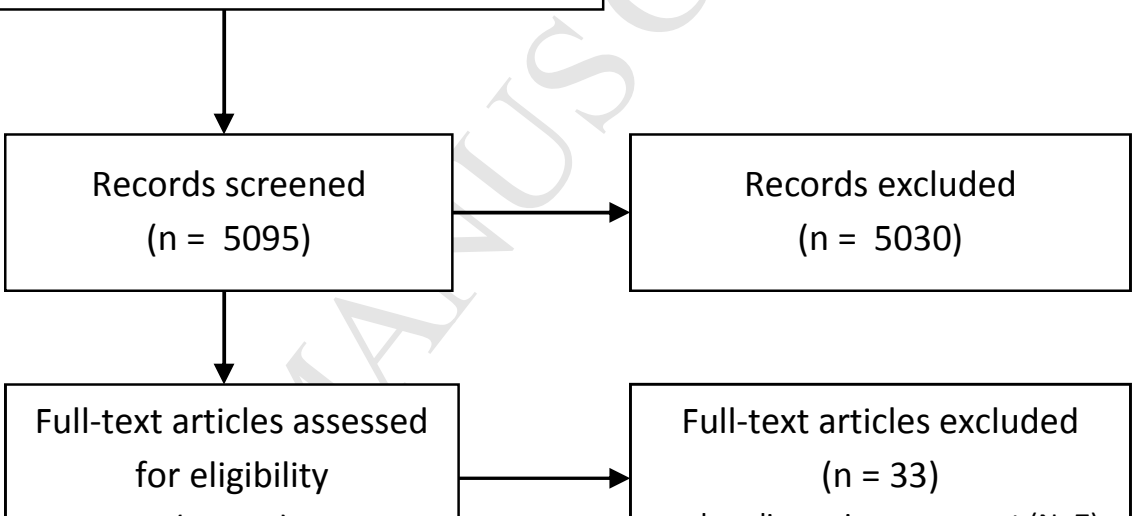

no baseline pain assessment $(\mathrm{N}=7)$ no control group $(\mathrm{N}=6)$ unsuitable depression group $(\mathrm{N}=5)$ no pain measure $(\mathrm{N}=6)$

Studies included in qualitative synthesis no response to data request $(\mathrm{N}=5)$ review article $(\mathrm{N}=2)$ duplicate publication $(\mathrm{N}=2)$

Studies included in quantitative synthesis

(meta-analysis)

$$
(n=32)
$$


Sucty name

Schwier et al (2010)

Bär et al (2003).

Bär et al (2005).

Ben-Tovim \& Schwartz (1981)

Bär et al (2007)

Bär et al (2011)

Dworkin et al (1995)

Lautenbacher et al (1994)

Otto et al (1989)

Rodriguez-Raecke et al (2014).

Adler \& Gattaz (1993)

von Knorring \& Espvall (1974).

Terhaar et al (2010)

Terhaar et al(2011)

Davis et al (1979)

Lautenbacher et al (1999)

Spernal et al (2003).

Piñerua-Shuhaibar et al (1999)

Klatzkin, et al (2010).

Fillingim et al (1995)

Euteneuer et al (2011)

Klauenberg et al (2008)

Strigo et al(2008a)

Normand et al (2011)

Zambito Marsala et al (2015)
Statistics for each study

\begin{tabular}{|c|c|c|c|}
\hline $\begin{array}{c}\text { Hedges's } \\
\text { g }\end{array}$ & $\begin{array}{c}\text { Loner } \\
\text { limit }\end{array}$ & $\begin{array}{l}\text { Upper } \\
\text { limit }\end{array}$ & p-Value \\
\hline 1.426 & 0.743 & 2.109 & 0.000 \\
\hline 1.177 & 0.517 & 1.837 & 0.000 \\
\hline 1.096 & 0.559 & 1.632 & 0.000 \\
\hline 1.005 & 0.015 & 1.995 & 0.047 \\
\hline 0.939 & 0.152 & 1.726 & 0.019 \\
\hline 0.868 & 0.260 & 1.476 & 0.005 \\
\hline 0.803 & 0.272 & 1.334 & 0.003 \\
\hline 0.775 & 0.144 & 1.406 & 0.016 \\
\hline 0.667 & -0.028 & 1.362 & 0.060 \\
\hline 0.623 & 0.015 & 1.232 & 0.045 \\
\hline 0.613 & -0.079 & 1.305 & 0.083 \\
\hline 0.513 & -0.015 & 1.040 & 0.057 \\
\hline 0.494 & -0.061 & 1.048 & 0.081 \\
\hline 0.461 & -0.071 & 0.994 & 0.090 \\
\hline 0.312 & -0.060 & 0.683 & 0.100 \\
\hline 0.297 & -0.452 & 1.046 & 0.437 \\
\hline 0.252 & -0.351 & 0.855 & 0.412 \\
\hline-0.009 & -0.681 & 0.663 & 0.979 \\
\hline-0.152 & -0.904 & 0.600 & 0.692 \\
\hline-0.240 & -1.145 & 0.666 & 0.604 \\
\hline-0.510 & -0.942 & -0.078 & 0.021 \\
\hline-0.593 & -1.151 & -0.035 & 0.037 \\
\hline-0.862 & -1.592 & -0.132 & 0.021 \\
\hline-0.874 & -1.384 & -0.364 & 0.001 \\
\hline-0.875 & -1.426 & -0.324 & 0.002 \\
\hline 0.317 & 0.050 & 0.585 & 0.020 \\
\hline
\end{tabular}

Hedges's g and $95 \% \mathrm{O}$

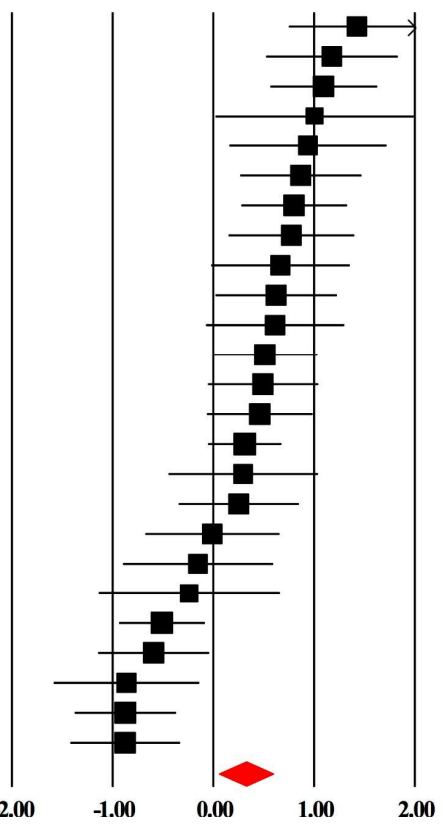

Decreased - Increased Pain Threshold (in depression) 


\section{Highlights}

- Meta-analysis of 32 experimental pain studies compared depressed vs. controls

- Higher overall pain threshold in depression but strong heterogeneity evident

- No differences in pain tolerance

- Depression and pain link may be dependent upon type of pain stimulation 